X-plained: The Production and Reception History of Douglas Coupland's Generation X

\title{
Christopher Doody*
}

Welcome to the overnight and highly charmed success story of Generation X.

- Douglas Coupland ${ }^{\mathrm{I}}$

\section{Introduction}

Generation X ... is a novel that has achieved widespread popular recognition. According to the perverse logic of the literary establishment, its popularity calls into question its validity as a literary text. And yet this is a novel worth looking at seriously, if only for the influence it has had on contemporary culture.

- G.P. Lainsbury ${ }^{2}$

Douglas Coupland's novel Generation X: Tales for an Accelerated Culture was among the five novels chosen for CBC's zoro Canada Reads contest. It was, however, eliminated within the first two days, alongside Ann-Marie MacDonald's novel Fall On Your Knees. Both books were deemed poor contestants for the contest, by the celebrity judges and readers alike, because they were already wellknown Canadian novels. This dismissal, however, raises the question of how well Canadians, or the world for that matter, really know Coupland's novel. Although most Canadians today might accept that this novel is part of the Canadian canon, consider these two

* Christopher Doody is a Master's candidate in English (Public Texts) at Trent University. His thesis examines the paratextual and ergodic elements of Douglas Coupland's novels. He would like to thank Zailig Pollock, Elizabeth Popham, and the two anonymous readers for their invaluable suggestions.

I Douglas Coupland, "Douglas Coupland on How He Came to Write Generation $X$," Guardian [London], 26 September 2009.

2 G.P. Lainsbury, "Generation X and the End of History" in GenXegesis: Essays on "Alternative" Youth (Sub)Culture, ed. John M. Ulrich and Andrea L. Harris (Madison, WI: University of Wisconsin Press, 2003), I84. 
reviews written a few months apart in the fall of 1992, the year after the novel's release. Brian Fawcett writing in Books in Canada notes, "Those of us who write about writing would have to be very deep inside our privileged comas not to recognize that Generation $X$ had, by a country kilometer, the biggest impact of any work of literature published by a Canadian in the last few years. It gave a heretofore voiceless generation not just an articulate and witty spokesperson, but a lexicon and a phenomenology as well." ${ }^{3}$ Aritha van Herk, on the other hand, writing in the University of Toronto Quarterly, viewed the novel in a vastly different light. She explains that the novel "exhibit[s] a desperate desire to prove [itself] socially relevant, but in the process show [s itself] to have little sustaining interest or value. In [its] attempts to enact radicalism, [it] succeed[s] only in achieving the banal."4 If literary critics were so diametrically opposed on the social impact of the novel twenty years ago, how have we arrived at such a complacent agreement on the novel today that it is no longer worthy of debate? Or is it perhaps that we have simply forgotten, or do not know, the novel's true history? This essay attempts to provide such a history of the text, which will offer a better understanding of Coupland's novel, and by extension, Coupland himself.

Like Generation X, Coupland has attained a sort of complacent acceptance in Canadian society, as the proverbial "always a bridesmaid, but never a bride" of Canadian literary celebrity. While his fame earned him a spot among the National Post's recent list of "ro Overrated Canadian Authors," alongside writers like Michael Ondaatje, Jane Urquhart and Yann Martel, he lacks something that all the others on the list possess-namely, a major literary award. Coupland has written fourteen novels in the last twenty years and has not a single literary award to show for it. He has, however, received a few "nods": his novel jPod and Player One have both been long-listed for the Giller Prize, and he had the privilege of being asked to give the Massey Lecture in 20IO. Despite his large body of novels, almost all of which have been bestsellers, he lacks the cultural capital of Canada's "true" literary celebrities, such as Atwood and Ondaatje. Attempts to pigeonhole Coupland as a shallow ironist-_[Coupland's] army

3 Brian Fawcett, "Malaise of the Mall-Raised," Books in Canada (October 1992): 45 .

4 Aritha van Herk, "Letters in Canada I99I: Fiction," University of Toronto Quarterly 62 (Fall 1992): 4.

5 Alex Good, and Steven W. Beattie, "Don't Believe the Hype: ro Overrated Canadian Authors," National Post, 24 August 2010. 
of fans and supporters [have] elevat[ed] him to the status of CanLit's premiere ironist, a designation that would be more appropriate if his ironies were a bit less obvious and more penetrating" - - seem to reflect that he is not an author worthy of serious study.

However, far from being a simple ironist, Coupland is an author in the truest sense- an author of both the text and the design of his novels, and the author of himself as author. A consideration of this careful crafting and self-crafting may lead to a new view of Canada's literary bridesmaid. In the late I990s, after the success of his first five novels, "[Coupland's] agent sent around a proposal for Miss Wyoming [Coupland's sixth novel], with a twist: publishers were asked not just how much they would pay for the manuscript, but how they would shape it, and, for that matter, Coupland's career. There were lots of responses. ('It's nice to know you're still wanted at the party,' Coupland says.)"7 This quotation begins to show Coupland's true concerns. Not simply concerned with monetary compensation, he wants to ensure that the editors of his text are aware of the image that he is crafting, both on the page and off. This crafting by Coupland as both a novelist and a literary figure can be traced back to the beginning-Generation $X$.

\section{McKenzie and the Sociology of a Text}

This essay offers a sociology of a text, namely Generation $X$. The methodology comes from the theories of D.F. McKenzie, which not only embrace the material aspects of a text, but also what this materiality can tell critics, and readers, about the production and dissemination of the text. As McKenzie explains, "the principle I wish to suggest as basic is simply this: bibliography is the discipline that studies texts as recorded forms, and the process of their transmission, including their production and reception." ${ }^{8}$ For McKenzie, the publication process of a text is as important as the creative process of the author, and it is essential to study a text's reception, for a text

6 Good and Beattie, "Don't Believe the Hype."

7 Fred Bernstein, "Entertaining Mr X," Sunday Review [Independent], 27 February 2000.

8 D.F. McKenzie, "The Book as an Expressive Form," in Bibliography and the Sociology of Texts (Cambridge: Cambridge University Press, 1999), I2. 
"is not even in any sense 'finished' until it is read." As McKenzie explains, "for any history of the book which exclude[s] study of the social, economic, and political motivations of publishing, the reasons why texts were written and read as they were, why they were rewritten or redesigned, or allowed to die, would degenerate into a feebly degressive book list and never rise to a readable history." ${ }^{\text {"o }}$ This essay is such a "readable history" of the novel Generation X.

Most of the information in this essay is taken from dozens of book reviews and profiles of Douglas Coupland and his novels. Presumably, the reporters who wrote the original articles either interviewed Coupland or his publishers to acquire the information. So, although the facts are received from a third party, I treat them as equally relevant, for three reasons. First, literary critics and reviewers of the novel are also readers of the novel, and their commentary offers an interesting insight into the novel's reception. Second, the information found in these reviews, even if subsequently proven to be inaccurate, nonetheless may have influenced some readers of the novel. I am not interested in the validity of a "fact" or statement made about a text, only in the fact that the statement presented in public had the potential to affect how the book was perceived. As a result, all the comments and information from reviews which are cited in this essay, even if proven to be factually incorrect, are necessary to the text's history and demonstrate the ways in which Coupland has crafted the narrative of himself as author. Third, I do not consider the author as the highest authority on a text, and expect that this study, if nothing else, will demonstrate why this is a wise decision. Coupland rarely tells the same version of events twice. Consequently, the literary critics who rely on his commentary are no less trustworthy than the author himself. In an attempt to provide a "readable history" of Generation X, I had to ensure that these various versions of events did not diminish this readability. As the result, the body of the essay offers a narrative of the novel's creation, dissemination, and reception. Contradictions and variants of this story, which are arguably more important than the main narrative itself, appear as footnotes. Hence, the footnotes and their relationship to the main text are vital to the "complete" story of Generation X.

9 D.F. McKenzie, "The Sociology of a Text: Orality, Literacy, and Print in Early New Zealand," in The Book History Reader, 2nd ed., ed. David Finkelstein and Alistair McCleery (New York: Routledge, 2006), 206.

Io McKenzie, "The Book as an Expressive Form," I3. 


\section{Publishing Generation X: A History}

Wherever the germ of the idea for Generation $X$ came from, the first piece published by Coupland on the topic appeared as a five-page article in the September 1987 issue of Vancouver magazine. The article was written as a non-fiction account of Generation X, a term which "denotes a large chunk of the population ignored because its members have no money and because Baby Boomers outnumber them,"II who were fed up with being grouped with the Baby Boomers. The next public appearance of Generation X was in $1988-90$ in the form of cartoons with text by Coupland and illustrations by Paul Rivoche. The cartoons appeared in Vista, ${ }^{\text {I2 }}$ a short-lived Torontobased business magazine. After this, the history becomes complicated and contested.

Shortly after he began working at Vista, Coupland acquired Peter Livingston $^{13}$ as a literary agent, and by 1989 they were approaching publishing houses with a proposal for Generation $X$. The proposal pitched a non-fiction book, in which Coupland would enlighten readers about the generation following the Baby Boomers: "In GENERATION X readers get the facts: the attitudes and expectations of Xers as a generation destined to grow up in a world very different from that of ... generations before them. [It] combines startling statistical and demographic research with a humorous and accurate narrative to present an idiosyncratic but bang-on picture of the bodies

II Douglas Coupland, “Generation X," Vancouver Magazine, September 1987, I69.

I2 Vista was a monthly magazine in print from 1988 until May I990, with fourteen issues in total. Every issue had a "Generation X" cartoon, usually two pages in length.

I3 David Johnston was working for Peter Livingston at the time that Livingston was working on Generation $X$. Johnston was very involved in the project of pitching the novel, and I have talked to him about his involvement in the novel's publishing history. All quotations from Johnston come from this personal correspondence. Johnston notes, "the Livingston Agency was small (staff of three-and-a-half) and we tended to work quite closely together on projects, often round-tabling them. Peter asked for my input (being the same age as Coupland) and that of our associate Janine Cheeseman ... when it came to evaluating how Doug's ideas resonated with its target demographic. We ended up spending several months working with Doug on the proposal, which was and remains one of the more elaborately designed [proposals] I've ever worked on (lots of graphic design, illustrations and side-bars)." (David Johnston, e-mail message to author, 22 September 20Io.) 
and souls of Xers - and the world they will inherit"I4 (emphasis in original). Apparently, twelve to fifteen Canadian publishers, ${ }^{15}$ as well as fifteen American publishers, rejected Generation X, before Coupland's agent "sold the idea of Generation $X$ to both a Canadian and an American publisher." ${ }^{\text {"I }}$ In Canada, "the book was acquired by Dean Cooke, publisher [of] Seal Books," ${ }^{17}$ and in the United States by James Fitzgerald of St. Martin's Press. It is not clear, however, how the relationship with his publishers began. Some versions of the story have Coupland, with the help of Livingston, proposing the book to his publishers, ${ }^{18}$ while other versions have the publishing houses approaching and commissioning Coupland. ${ }^{19}$ The former version of

I4 Overview of Generation $X$ as book proposal, [c. 1987-I991], Douglas Coupland Fonds, Box 009, File I4, University of British Columbia Library, Special Collections, Vancouver. All further archival references are to this collection.

Is "He tried a dozen Canadian publishers [before going to St. Martin's Press]"; "Generation X was rejected by Is Canadian publishers"; "Generation X was pitched to, and rejected by, as many as two dozen Canadian and American publishers"; "GenX was rejected by almost two dozen Canadian and American publishers." (Scott Lawrence, "King of Hip" Gazette [Montreal], 20 September 1992; Ellen Saenger, "The X-man Writeth," British Columbia Report, I8 November I99I; Dan Rowe, "Coupland's World," Quill \& Quire (January-February 2006): I7; Rod McQueen, "End to Identity Crisis of Generation X," Financial Post, 2 November 1992.)

I6 Coupland, "On How He Came to Write."

17 Johnston, e-mail to author, 22 September 2010.

I8 "The cartoon [in Vista magazine] ... helped sell St. Martin's on the idea of a book"; "It all started when Toronto agent Peter Livingston (now deceased) thought it would be a good idea if Coupland put together some kind of Generation $X$ handbook"; " $X$, as Coupland calls it, was originally pitched as a guide-book ... St. Martin's Press took the bait"; "Peter [Livingston] and I worked together on pitching [the] idea to publishers both in NYC and Canada." (Carla Lucchetta, "X Years After: Postscript for a Generation," Vancouver Sun, January 27, 200I; Dona Sturmanis, "Doug Coupland and That's How They All Became the Gen-X Bunch," Vancouver Step, December I99I-January I992; Rowe, "Coupland's World," I7; Johnston, e-mail message to author, 22 September 2010.)

I9 "The publisher had commissioned Canadian-raised Coupland"; "He was commissioned by a New York publisher to write a lifestyle guide for his generation"; "When they asked me to do a handbook on the generation" (emphasis added); "St. Martin's Press in New York asked him to write a guide to Generation X"; "Coupland was writing a cartoon strip called 'Generation X' for a Toronto business magazine when St. Martin's Press took notice of him. The publishing firm asked him to write a lifestyle guide for his generation." (Stephen McCauley, "The Next Generation," Vogue, September 1992, 368; Michael Neill, and Nancy Matsumoto, "X Marks the Angst," People Weekly, I4 October I99I, IO5; Gilbert A. Bouchard, "Coupland No Spokesperson," Edmonton Journal, 
the story seems to make the most sense, but the abundance of reviews which report the latter version complicates the narrative. Nonetheless, the result is clear: St. Martin's Press and Seal Books both had an agreement with Coupland that he would write a non-fiction book, as a sort of guidebook to his generation. Coupland was paid an advance, the amount of which is not clear. Coupland refers to the advance as a "student loan," ${ }^{20}$ but it was probably between $\$ 15,000-20,000,{ }^{2 \mathrm{I}}$ which Coupland may have had to repay. ${ }^{22}$ In $1989,{ }^{23}$ Coupland cashed in his advance, "bought a blue Volkswagen 197I," moved to a bungalow "off Sunrise way" ${ }^{24}$ in Palm Springs, California, and spent "nine months" 25 writing the manuscript for Generation X. Coupland

I3 September 1992; Chris Dafoe, "Carving a Profile from a Forgotten Generation," Globe and Mail, 9 November 1991; Stephanie McKinnon, "Generation X," Desert Sun [Palm Springs], 6 September I99I.)

20 Elizabeth Manus, "The Book Editors Who Came in from the Cold," New York Observer, 2I March 1999; Marianne "His Generation," Village View, 28 August3 September 1992; McQueen, "End to Identity Crisis."

${ }^{21}$ "Coupland got a $\$ 22,500$ advance to write "Generation X”"; "Mr. Fitzgerald [Coupland's editor at St. Martin’s Press] paid around \$15,000 for the book about twentysomething slackers"; "St. Martin's Press in New York offered a modest advance in the low five-figures." (Steven Lohr, "No More McJobs for Mr. X," New York Times, 29 May I994; Manus, "The Book Editors"; McQueen, "End to Identity Crisis.")

22 "He ended up paying back his original advance"; "If I had to pay the advance back, it'd be like a student loan." (Bouchard, "Coupland No Spokesperson"; McQueen, "End to Identity Crisis.") I speculate that Coupland may have had to repay the portion of the advance he received from Seal Books when the publisher cancelled the contract, but not the portion he received from St. Martin's Press. As David Johnston told me, "we only had two offers, both of them modest, but together enough to provide a living wage while Doug wrote the book." This suggests that each publishing house provided part of the advance; hence, Coupland may very well have had to repay the advance he received from Seal.

23 It is unclear when in 1989 Coupland began working on Generation X. One review suggests October 1989 (Sturmanis, "That's How They All Became”). If it took nine months to complete the manuscript as Coupland claims, this would mean the manuscript was finished in June 1990. Since Coupland is quoted as saying that he submitted the manuscript to his publishers on April I, it is likely he started writing the novel earlier than October 1989, or that it did not take him nine months to complete the work.

24 McKinnon, "Generation X."

25 Sturmanis, "That's How They All Became"; Doug Ward, "Separated at Birth from Boomer Bliss,” Saturday Review [Vancouver Sun], 8 February 1992; Andrew Strickman, "Global Teens on a Shampoo Planet," Boston Tab, I September 1992. Although this fact is often cited, it is countered by other dates given by Coupland as to when he started and finished the manuscript (see footnote 23). Nine months gestation may have been cited for its evocation of a pregnancy, as 
explains that "I FedEx'd the manuscript to [my publishers in] New York and Toronto on I April [1990]." He then "began to wait and wait and wait and wait for a response. None came ... By midsummer I learned that the Canadians ${ }^{26}$ had rejected the book outright (I have a weirdly snippy letter from them somewhere) and the US publishers were going to delay the book indefinitely." 27

Coupland was now down to just one publisher, St. Martin's Press, which "had originally scheduled the book for a fall release, [but] then pulled it due to what seemed to be a chronic lack of enthusiasm." 28 The novel was finally released the following spring, on is March I99I. ${ }^{29}$ The original print run was either 3,000 or I0,000, ${ }^{30}$ and St. Martin's Press had apparently "halved the [first] print run." ${ }^{31}$

Although Coupland had a contract with his publisher to write a non-fiction book, he submitted a work of fiction, known today as Generation X. Trying to determine when this change from non-fiction to fiction took place is almost impossible. It is clear that the original idea for the text, as seen in the article published in Vancouver magazine in 1987, was a work of non-fiction. In the Douglas Coupland fonds, housed at the University of British Columbia, there are a few copies of the book proposal for Generation X. Assuming that these are drafts/ versions of the proposal that his publishers received, it is clear that Coupland originally saw Generation $X$ as a work of non-fiction. All articles support this version, ${ }^{32}$ most noting that the proposed book

opposed to a factual statement about the amount of time it took to write the manuscript.

26 "The Canadians" refers to Seal Books. As David Johnston notes, "It is well known that, when Coupland delivered a novel instead of the proposed non-fiction book, Seal's sales and marketing people felt they couldn't sell it and cancelled the contract" (e-mail message to author, 22 September 2010).

27 Coupland, "On How He Came to Write."

28 Luchetta, "X Years after." This "lack of enthusiasm" can also be seen in the binding of the first edition, which will be discussed later in this essay.

29 The copyright page of the first edition states that it was printed in February I991.

30 Rowe, "Coupland's World"; John Marchese, "The Short Shelf Life of Generation X," New York Times, I8 June 1995.

3I Cotter, "His Generation."

32 "Coupland's original idea was to do it as a non-fiction work in the style of The Preppie Handbook, which had been a hit in the mid I980s"; "The original idea was for a book on the order of The Official Preppy Handbook"; "He was commissioned by a New York publisher to write a lifestyle guide for his generation-something like The Official Preppy Handbook"; "St. Martin's Press in New York asked him to write a guide to Generation X-something on the model of the Yuppie 
was to imitate the 1980 The Official Preppy Handbook edited by Lisa Birnback, "a tongue-in-cheek humor reference guide ... [describing] an aspect of North American culture [referred to] as prepdom" 33 that was popular in the 1980s. Essentially, "[Coupland's] mandate was to 'accurately convey how [his] birth cohorts perceive the world."'34

Although most articles suggest that Coupland's original intention to write the book as non-fiction was in earnest, some seem to suggest Coupland hoodwinked his publisher. ${ }^{35}$ Either way, sometime during the writing process, Coupland decided to write a novel. He is quoted as having said, "I didn't think the world needed one more dopey handbook." ${ }^{6}$ In 2009, Coupland explained the moment when he realized the work had to be written as a piece of fiction:

One afternoon in April of 1989, I was emerging from the Davisville subway station-there had just been a rainstorm and the sunset was cold and tangerine-and a wave swept over me, one of those waves that occur not too often in one's lifetime. It was one of the few times I've ever heard 'a voice' (whatever a voice really is), and the voice very clearly said to me: 'OK, Doug. It appears that you're going to be a full-time writer now. Good. But that means you have to write fiction rather than non-fiction, because fiction is purer. You'll have to clear all your decks and you're going to have to change the way you see both you and your future. ${ }^{37}$

Despite the change from non-fiction to fiction, most reviewers viewed the marginalia and appendix of the book as remnants of the

Handbook"; "The publishing firm asked him to write a lifestyle guide for his generation — something like 'The Official Preppy Handbook' of the early I980s." (Luccheta, "X Years after"; Stephen McCauley, "The Next Generation," Vogue, September 1992, 368; Neill, "X Marks the Angst"; Dafoe, "Carving a Profile"; McKinnon, "Generation X.")

33 Wikipedia, s.v. "The Official Preppy Handbook," http://en.wikipedia.org/wiki/ The_Official_Preppy_Handbook (accessed i9 July 20I0).

34 Sturmanis, "That's How They All Became."

35 "X, as Coupland calls it, was originally pitched as a guide-book to the generation born between the I960s and the late I970s. St. Martin's Press took the bait, and Coupland then submitted a novel"; "'It wasn't a novel at first.' 'Yes, it was,' Coupland says. 'It was always a novel. It was never anything else.' But didn't the publisher ask for a handbook? 'Well, yes. 'Generation X' was supposed to start as a handbook,' Coupland says. 'But from the first sentence onward it was a novel."” (Rowe, "Coupland's World," I7; Stephen Whitty, "Of Global Teens and Glumsters," Scene [Santa Barbara News-Press], 23 October 1992.)

36 McKinnon, "Generation X."

37 Coupland, "On How He Came to Write." 
non-fiction intention. ${ }^{38}$ Coupland, however, did not discuss this change of plans with his publisher. "They never asked to see it while I was writing,' [Coupland] said, 'so I handed in a novel."'39 James Fitzgerald, Coupland's editor at St. Martin's Press, admits that "it was completely different from what I bought." ${ }^{\circ}$ Coupland explains: "To [James Fitzgerald's] credit ... he didn't take me to court. I am not sure what went on at St. Martin's after I handed it in, but everyone had read it and there was a big debate. The junior staff in the company were my staunch supporters. ${ }^{4 \mathrm{I}}$ I owe everything to them.." ${ }^{22}$ Fitzgerald, "confirmed that there was some behind-the-scenes discussion about the book," 43 but in the end, St. Martin's Press decided to print it. Although Coupland has said that St. Martin's published the original manuscript "as it was, ... no one sat down and agonized over it," 44 this is not true. The Coupland fonds includes a manuscript copy of Generation $X,{ }^{45}$ labeled "Fitzgerald Copy." This manuscript has been

38 "Coupland decided it would be too much like an '8os guide book, and settled on a novel, with some X-generation definitions thrown in for good measure"; "It was only during the writing process that it morphed into a novel, with a non-fiction glossary relegated to marginalia status"; "Instead, Coupland wrote a novel. The cartoons, illustrations, and glossary of trendy terms, described by the editor as 'thought bombs,' were confined to the book's wide margins"; "Instead he began writing fiction, and the glossary of Xer slang joined his illustrations and assorted slogans as margin notes." (Saenger, "The X-Man Writeth"; Lucchetta, "X Year after"; McCauley, "The Next Generation," 368; Neill, "X Marks the Angst.")

39 Quoted in Robin Abcarian, "Boomer Backlash," Los Angeles Times, I2 June I991.

40 Quoted in Lohr, "No More McJobs for Mr. X."

4I A few reviewers note that Coupland's manuscript was saved due to the support of junior, or 'Generation X,' staff members at St. Martin's Press: “'There was great support from Generation Xers and a little concern from people who were older [than] the marketing staff,' said Fitzgerald. 'I said, "You either get it or you don't." There are still people here who don't get it"”; "Junior editors rallied behind the book, though"; "One editor, Jim Fitzgerald ... championed the book and convinced St. Martin's to publish it"; "My good fortune was that the younger staff at the US publisher became vocal in their demand that the book be published, which occurred ever so grudgingly in March of 199I." (Abcarian, "Boomer Backlash"; Whitty, "Of Global Teens"; Rowe, "Coupland's World," I7; Coupland "On How He Came to Write.")

42 Quoted in Abcarian, "Boomer Backlash."

43 Abcarian, "Boomer Backlash."

44 Sturmanis, "That's How They All Became."

45 Fitzgerald's copy of Generation X manuscript, [c. 1987-I99I], Douglas Coupland Fonds, Box 075, Files 06-09. 
edited, and even with these edits, the manuscript differs from the final published text, suggesting a second round of edits took place as well. ${ }^{46}$ Whatever the reason, it appears that St. Martin's Press did not expect Generation $X$ to become a bestseller. The first edition was poorly printed, as is discussed below, and it has been reported that St. Martin's Press did very little to promote the book. ${ }^{47}$ As Coupland says, "Generation X's tiny, March I99I printing had no publicity, and received almost no reviews." ${ }^{48}$ It is not clear how much publicity St. Martin's Press undertook. Fitzgerald says that "he and his assistant mailed posters and post cards to anyone they thought might appreciate the book," and David Johnston notes, "St. Martin's agreed to a street level marketing campaign papering U.S. campuses with posters and postcards featuring some of the slogans that appeared in the book." 49 St. Martin's Press did also create an advanced reading copy of the novel that was sent to reviewers in November 1990. Regardless, the book received almost no reviews upon its release, aside from a review in the February 1991 issue of Rolling Stone, which Coupland recalls vividly. "[Coupland] remembers reading one lonely advance review in the Jan. IO, 1991 issue of Rolling Stone ${ }^{50}$ as he sat dejectedly in the Montreal subway. '[Generation X] captures the listlessness that

46 The Coupland fonds also includes a copy of an undated letter Coupland sent to his editor concerning the editorial changes to the manuscript. It begins: "Jim [Fitzgerald]... A few notes on your notes. They were all good..." Perhaps more interestingly, however, is the end of the letter, where Coupland reveals his deepest worry about Generation X: "My main concern, Jim, has been that the writing anywhere in this book would in any way be construed as: anguished, maudlin, sophomoric or overwritten. You noted two paragraphs ... that seemed 'writer's class-ish.' (horror!) and then I got to wondering, 'Well, gee, maybe there are other writer's class-ish paragraphs in the book somewhere.' Are there? I'd rather you were cruel now rather than have Michiko Kakutani dump on it come January. (We should be so lucky as to get a NY Times review.) Does St. Martin's have some form of infra-staff process whereby a 'Criticism-o-meter' is held up to a work to measure its broad-based appraisal?” (Douglas Coupland to James Fitzgerald, [c. I987-I99I], Douglas Coupland Fonds, Box oro, File 04.)

47 “St. Martin's Press did little to promote Generation X when it was released in early I99I and they halved the print run. Predictably, it flopped, which confirmed Coupland's worst fears about the weird little book he'd written." (Cotter, "His Generation.”)

48 Coupland, "On How He Came to Write."

49 Quoted in Manus, “The Book Editors”; Johnston, e-mail to author, 22 September 2010.

so This article is incorrectly identified. Generation $X$ was not reviewed in the January issue of Rolling Stone. Coupland is most likely referring to the 7 February I99I issue. The confusion might be due to the fact that magazines often release issues 
accompanies growing up in today's info-laden culture, ${ }^{, 51}$ read the notice. Listlessness Coupland knew ... [He] had received five advance copies from the publisher and all were incorrectly bound. 'Instead of saying, 'Hey, we have something people might want to read!' they said, 'It can't last,' Coupland recalls." "52 It is difficult, twenty years later, to determine exactly how well the book sold in the first few months of its release. Most book reviews suggest that the book had a very slow start, and most of its sales could be attributed to word-of-mouth publicity, especially on campuses. ${ }^{53}$ My own research supports this claim-I found fewer reviews published in the first six months after the book's release than in subsequent months. Yet, by September 199I, a reviewer notes that the book was in its "fifth printing." ${ }^{4}$ This suggests that even if newspaper reviews were not fueling the sales of the book, something else was driving its growing popularity among readers. This version of events, in which the book-buying public saved the book, is exemplified by this late review from Books in Canada: "Never mind that the book couldn't find a Canadian publisher, that the Globe and Mail didn't review Generation X, ${ }^{55}$ or that Books in Canada crammed it into the sleep-inducing critical mill of its First Novels column, ${ }^{56}$ where it was rejected for having an attitude problem. We were rescued by, of all things, the book-buying public, a great many of them under

one month in advance. So Coupland could have read the February issue of the magazine in January or he may have been misquoted.

5I The quoted line actually reads "[Generation X] attempts to capture..." (emphasis added).

52 Lucchetta, "X Years after."

53 "Largely through word of mouth, Generation $X$ gained a mini cult status, becoming a campus favorite"; "The novel became a word-of-mouth phenomenon, spreading first through universities and colleges, then to the top of bestseller lists around the world"; "With virtually no publicity, it became (to just about everyone's surprise) an enormous hit. How? Mostly by word of mouth, mostly in the university and college communities where the people and the culture the book talks about live." (McCauley, "Next Generation," 370; Matthew Mallon, "Generation X Man,” Monday Magazine, 22-28 October 1992; Lawrence, "King of Hip.")

54 McKinnon, "Generation X." It is difficult to determine the size of each printing of the novel. Based on the numbers of books sold, reported in various book reviews, it seems that by the sixth printing, 80,000-100,000 copies of the book had been printed in North America. One review, dated November I99I, notes "the book is in its sixth printing-more than I00,000 copies have been published-in the U.S." (Saenger, "The X-Man Writeth.")

55 This is not true. See Dafoe, "Carving a Profile."

s6 Laurel Boone, "First Novels (The Self Indulged)," Books in Canada (September I99I): 50-5I. 
30, who put this remarkable book on the Canadian and US bestseller list and have kept it on the Canadian list ever since." 57 While the romantic notion of the book-buying public saving a book from grouchy critics might be appealing, it is not without its problems. In the Coupland fonds, there is a copy of a fax Coupland sent to Anne Garner of W.H. Smith, one of Canada's larger book distributors at the time. In the fax, dated 23 July 1991, Coupland urges Garner to order more copies of Generation X, promising it will sell, noting that the first printing had sold out, and four foreign language rights had already been sold. ${ }^{58}$ The fax also lists seven prominent newspapers and magazines which had reviewed the book. ${ }^{59}$ It seems likely that Coupland is posing as the confident salesman in this fax, casting his book in the best possible light, listing perhaps not the book's best reviews, but its only reviews. If the book was as popular as Coupland insists, then arguably Garner would know of it already, or would have noted its strong sales. It would appear, then, that Generation $X$ had a slow start. This all changed, however, in September I99I.

It is not clear what changed after the summer of 199I, but suddenly reviews of the book began to appear in the press in great numbers. Coupland acknowledged this shift: "And then something happened. I think it was September and suddenly the press stopped being so antagonistic to the notion that some different, younger sensibility might exist. I don't know what it was. I still can't put my finger on it. Everything that's happened to the book between then and now has been cumulative and incremental." ${ }^{\text {"60 }}$ By 7 December 199I, nine months after the book was published, it appeared for the first time

57 Fawcette, "Malaise of the Mall-Raised," 45.

58 The fax reads, in part:

I wrote a novel called Generation X. It's selling like crazy in the U.S. and the first printing is sold out ... It's been the subject of profiles in the L.A. Times and the Washington Post, it's a Q.P.B. selection and the Japanese, U.K., German + Italian rights are sold.

McClelland + Stewart is distributing Gen X in Canada but they're not pushing it. I think this is crazy. I wish W.H. Smith would carry it more. You'd be able to sell whatever you ordered. The U.S. chains have all bought big and are selling big so there is strong precedent.

You're the best Canadian chain and I really hope you'll chose to order Generation $X$. It's had reviews everywhere and the stores have big demand. Now it's a matter of filling that demand! (Douglas Coupland to Anne Garner (at W.H. Smith), [23 July 199I], Douglas Coupland Fonds, Box 084, File 09.)

59 They are: Details, Rolling Stone, Cosmopolitan, Detroit Free Press, Gazette [Montreal], New York News, Vancouver Sun.

6o Coupland quoted in Cotter, "His Generation." 
on the Globe and Mail's bestsellers list at number seven. The book became a regular on the list and, within a year, in December 1992, it was the year's bestselling book in Canada ${ }^{6 \mathrm{r}}$ Generation X's strong sales continued, and it remains in print to this day.

\section{Design of Generation $X$}

Generation X displays a heightened sense of textuality and an awareness of its status as material object. The distinctive typography and hectic use of paratextual material —including a witty postmodern glossary and acerbic cartoons - has no real precedent in contemporary fiction.

- Andrew Tate ${ }^{62}$

Despite the complicated and confusing publishing history of Generation X, one feature of the text has never changed-its design. Although the design of a novel may be viewed as extraneous to a sociology of a text, Gérard Genette would argue otherwise. In his work Paratexts, Genette argues that the design or "paratext" of a novel has "an influence on the public, and influence that-whether well or poorly understood and achieved-is at the service of a better reception for the text and a more pertinent reading of it." ${ }^{163}$ More importantly, this influence on the reader happens whether the reader is aware of it or not. As Genette notes, "I am not saying that people must know th[e] facts [found in the paratext]; I am saying only that people who do know them read [the] work differently from people who do not and that anyone who denies the difference is pulling our leg." ${ }^{" 64}$ In other words, the design of Generation $X$ is as vital to our understanding of its creation as any other aspect of its sociology.

61 Globe and Mail, "The Globe and Mail's Annual National Bestseller List," 26 December 1992. The second bestselling book of the year was Michael Ondaatje's Governor General Award and Booker Prize winning novel The English Patient. (To be fair, The English Patient was published in September 1992, giving it only three months to compete with Generation X.)

62 Andrew Tate, Douglas Coupland, Contemporary American and Canadian Writers (Manchester: Manchester University Press, 2007), II.

63 Gérard Genette, Paratexts: Thresholds of Interpretation, trans. Jane Lewin (New York: Cambridge University Press, 1997), 2.

64 Genette, Paratexts, 8. 
In twenty years, the unique design and layout of the novel, including its cover, has not changed. ${ }^{65}$ This, like much of Generation $X$ s history, is distinctive. Comments on the book's unique design have become commonplace in the critical literature since the beginning. Early reviewers suggested that it was "a novel disguised as a magazine article," that it had "the format of a design textbook," or that it "resembles ... a grade-school textbook." ${ }^{66}$ Not all critics enjoyed the design: "This is an infuriating novel. It's as wide as a textbook and floppy, so it droops in your hands like wet Wonderbread; the pages stick out beyond the cover, and the margins are littered with slogans, cartoons, and definitions of (Baby) boomerspeak." ${ }^{67}$ Regardless of the critics' views, the fact that a book's design bears mentioning in a book review is noteworthy. Although the book identifies Judith Stagnitto $^{68}$ as the novel's designer, and at least one review noted that "Coupland did not participate in the book's design," ${ }^{69}$ the facts are

65 This section only applies to the North American edition, published by St. Martin's Press. Foreign covers and designs vary dramatically, as it appears that Coupland, and presumably St. Martin's Press, had no control over foreign designs. In the Coupland fonds, there are a number of faxes notifying Coupland, after the fact, that his book is on sale in certain countries, and they sometimes include the new cover graphics.

66 The quotes in full are: "[Generation $X]$ reinforces its pseudo-documentary impression through design ... This is a novel disguised as a magazine article, an enticingly packaged consumer object as up-to-date as next month's Sassy"; "The experimentalism of the novel mostly consists of the fact that it presents itself in the format of a design textbook, with marginal comments, illustrations and definitions accompanying the text"; "The book's layout resembles that of a grade-school textbook"; "The book even stands out as a physical object with its oddball shape, desktop publishing-influenced typography and a cover that is screaming fluorescent orange on the bottom half and a blue, unnervingly cool, upside-down cloudscape on the top." (Michael Brockington, Five Short Years: Half a Decade of Douglas Coupland, 1996, http://www.sfu.ca/ - brocking/ writing/couplong.html (accessed 9 July 20IO); Norman Snider, "Camping It Up in California," Toronto Star, II May 1991; Nora Abercrombie, "Generation X: Cheerful to the End," Edmonton Journal, 23 June 199I; Andrew Wilson, "Writing about the Wrong Generation," Vancouver Sun, 5 September I992.)

67 Jim Boothroyd, "Lost Souls of the '90s," Montreal Mirror, 9-I6 May I99I.

68 In an article published much later [Judith Stagnitto Abbate, "Judith Stagnitto Abbate Describes Following Douglas Coupland's Visual Cues in Her Design of Generation X," CBC, 9 December 2009, http://www.cbc.ca/books/ $\mathrm{MT} / 2009 /$ I2/judith-stagnitto-abbate-describes-following-douglas-couplandsvisual-cues-in-her-design-of-generatio.html\# (accessed I9 July 20IO)], she uses the name Judith Stagnitto Abbate. In future references, she will be referred to as Abbate.

69 Sturmanis, "That's How They All Became." 
less straightforward. Arguably, four aspects of the book's design make it so unique: its physical size and shape, the marginalia, the layout of the chapter openers, and the cover. No single person was responsible for all four of these design aspects. It is therefore useful to examine each of these aspects in turn, assigning credit where it is due.

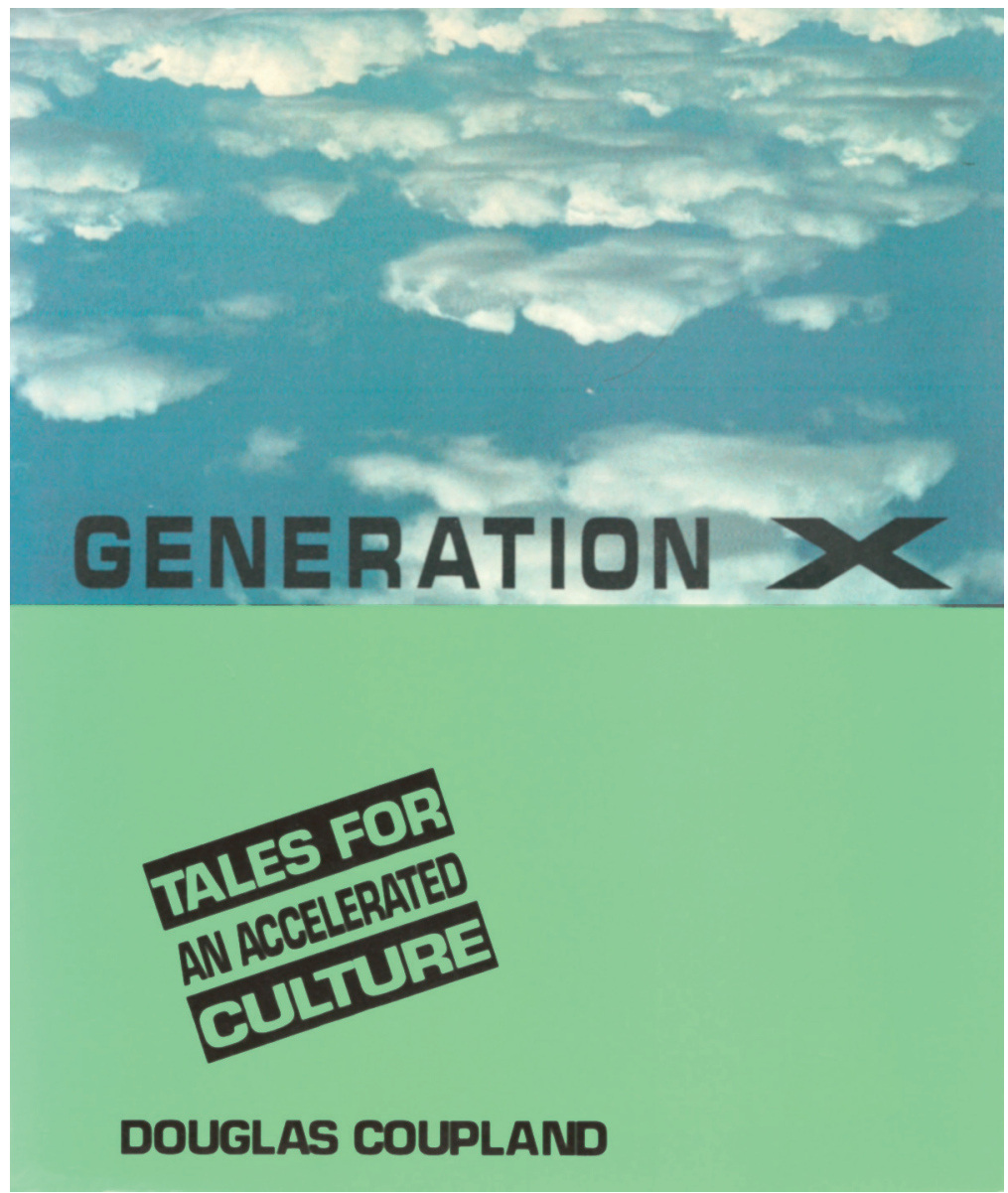

Figure I. The cover of the first edition of Generation X.

Generation $X$ was first published as a soft cover book of I83 pages, nine by eight inches in dimension. The book was literally "designed 
to stand out on a bookshelf." ${ }^{\circ}$ Abbate, the designer of the novel, credits the book's editor, James Fitzgerald, for its unusual size, which allowed for its uniquely large margins. ${ }^{7 \mathrm{I}}$ While it appears that great consideration was given to the design of the book, the binders were less attentive since the cover of the first edition was too short to completely cover the pages. Coupland took this inattentiveness to mean that his publishers did not care about his novel. ${ }^{72}$ The publishers quickly realized the book's true potential and corrected the binding error in subsequent editions. In fact, the popularity of the book produced the rare effect of seeing a hard cover release follow three years after the original soft cover release. ${ }^{73}$

Abbate explains the chapter openers as follows:

The sky [motif found on the book's cover] was used here, too, with an exaggerated halftone screen for 'grunge appeal' in keeping with the illustrations. After experimentation with various layouts, I decided to center it within the text block itself, where it seemed alternately expansive or claustrophobic: Depending on how you view it, it appears to be either a window piercing the text or a slice of sky imprisoned on all sides by structured lines-which felt apropos to the story. The rest of the chapter opener layout is a simple bisected page, to mirror the distinctive halved format on the cover. ${ }^{74}$

The chapter openers have another unique characteristic not mentioned by Abbate. To enhance the "text block" appearance on the first page of each chapter, there are no paragraph breaks. Instead, each new paragraph is identified with a symbol. Since the text is fully justified,

70 Sturmanis, "That's How They All Became."

${ }^{71}$ "The [need for space in a book's design is] never easy. While designers view expanses of white paper as evocative, publishers often looked on them with admittedly more practical eyes — as wasted space that should be filled to reduce the page counts and manufacturing costs. Luckily the editor, Jim Fitzgerald, was a step ahead. Always genuinely supportive of book design's impact on the final product, he'd requested a square trim size that allowed plenty of room next to the text for the various illustrations. It also provided the visual breathing space that I felt the story craved." (Abbate, "Following Douglas Coupland's Visual Cues.")

72 Coupland said: "Looking at [my copy of the first edition] I noticed that its cover didn't actually cover the pages, which stuck out maybe-in from the edge. When I asked my editor what were they thinking, I was told not to be so picky." (Coupland, "On How He Came to Write.")

73 St. Martin's Press published the hard cover edition of Generation X on 7 December 1994.

74 Abbate, "Following Douglas Coupland's Visual Cues." 
the result is an undisrupted block of text. G.P. Lainsbury notes "the omnipresent paragraph symbols and the cloud-motifs 'openings' at the start of each chapter - a stylistic tic that calls attention, through their absence, to the conventions of the literary presentation of material." 75 Although these design elements may appear inconsequential to the average reader, Abbate, among others, feels they are an essential part of the book's overall design.

The cover of Generation $X$ may be its most easily recognizable design feature. ${ }^{76}$ On the cover, as shown in Figure I, the top half depicts an "unnervingly cool, upside-down cloudscape," essentially "a huge patch of sky (or could it be an atomic cloud?)."77 The bottom half is a solid fluorescent colour. These two characteristics, the upsidedown clouds on top, and the fluorescent colour on the bottom, have remain unchanged for two decades in the North American editions. What did change, however, were the colours used on the cover. The first edition of Generation $X$ used a blue background on the top half of the cover (the clouds), and a neon green bottom. In subsequent printings, ${ }^{78}$ however, these colours changed, and frequently, "the result was that there were all these otherwise identical books slathered with all manner of fluorescence. And since there were so many to choose from, booksellers had to display them all." ${ }^{\prime 79}$ Consequently,

75 G.P. Lainsbury, "Generation $X$ and the End of History," I86.

76 The designer of the cover is not identified in the novel. Since Abbate is the designer named on the copyright page, readers might assume that she was responsible for the book's cover design. Abbate affirms, however, that she did not design the cover: "I'm partial to books with a sense of design continuity from front cover to index, so I knew I'd like to carry some element from the jacket through the interior. St. Martin's was blessed with a true symbiotic relationship between the cover and text design departments. We routinely wandered into each others' cubicles, coffee in hand, to trade design ideas. Because of this, I'd gotten a glimpse of the disturbing sky photo on the cover, and knew it was fraught with text-design possibilities." (Abbate, "Following Douglas Coupland's Visual Cues.")

77 Wilson, "Writing about the Wrong Generation"; Laurence Chollet, "Embraced by a Generation," Sunday Record, 3 November I99I.

78 I have not been able to determine which printing initiated the change of colour. In his review of the novel published on 5 September 1992, however, Andrew Wilson notes that the "cover [has] screaming fluorescent orange on the bottom half" (Wilson, "Writing about the Wrong Generation"). This suggests that within at least 16 months of the first printing, St. Martin's Press had introduced the new colours on the cover.

79 "Judging Books by Their Covers," Mastication Is Normal, September 2003, http:// www.cheshiredave.com/mastication/covers/200309/coupland.html, (accessed I2 July 20IO). 
when prospective buyers went into bookstores, they could choose from a range of coloured covers. ${ }^{80}$ The colours that were chosen for the covers, however, were not arbitrarily assigned. The colours were "selections from the DayGlo ${ }^{81}$ palette." ${ }^{22}$ Essentially, the colours are taken from a very specific colour palette, which itself is referred to by Coupland in one of his famous marginal definitions. ${ }^{83}$

The last major design feature of Generation $X$ is its marginalia. As with most aspects of the novel, critics disagree on the value of the marginalia. Some love it: ${ }^{84}$ "The marginal commentary is a stroke of design genius" ${ }^{85}$; others hate it: ${ }^{86}$ "The cartoons, definitions, slogans, and other ephemera running beside the text in a separate column make

80 "Maybe [the variously coloured covers] were an opportunity to force us lazy Gen-Xers into having to-perish the thought-make a decision: Which color cover would we buy? The choices were endful! [sic]" ("Judging Books by Their Covers," September 2003.)

8I DayGlo is "a proprietary name for a make of fluorescent paint or other colouring matter" (Oxford English Dictionary, s.v. "DayGlo," http://dictionary.oed.com/ (accessed i9 July 20I0).)

82 "Judging Books by Their Covers," September 2003.

83 "Black Dens: Where Black Holes live; often unheated warehouses with Day-Glo spray painting, mutilated mannequins, Elvis references, dozens of overflowing ashtrays, broken mirror sculptures, and Velvet Underground music playing in background." (Douglas Coupland, Generation X: Tales for an Accelerated Culture (New York: St. Martin's Press, I99I) I35.)

84 "A running glossary fills out the margins, along with spot ill[ustrations] and the occasional cartoon"; "In the absence of anything as uncool as plot, the marginalia are the best and wittiest parts"; "For the visually acute, the margins also sport the occasional cartoon that typifies some horrific aspect of the modern psyche. The odd woodcut slogan, ... also appears intermittently. The marginal commentary is a stroke of design genius, encouraging a pleasantly desultory examination of death and degradation"; "Deadpan cartoons by Paul Rivoche littered the book's margins along with catch phrases, or 'thoughtbombs'-instant jargon like McJob ... which have crept into everyday speech"; "Each page is decorated with definitions, slogans, cartoons, or statistics, all of which help define "Generation X" as those born between I96I and 197I." (Brockington, "Five Short Years"; Snider, "Camping It Up"; Abercrombie, "Generation X"; Mallon, "Generation X Man”; Chollet, "Embraced by a Generation.”)

85 Abercrombie, "Generation X."

86 "[The marginal notes are] distracting, but what's worse is that this is the Vancouver-born author's first stab at a novel, and it may well become one of the cult favourites of the '9os"; "Generation X's Unique Selling Point is its ... wide margins peppered with zappy neologisms ... cartoons and rather vapid sub-Jenny Holzer slogans ... All of which is OK for the first few pages but rather rapidly runs out of steam, as do the novel's pretensions to deep-and-meaningfulness." (Boothroyd, "Lost Souls of the '9os"; John Williams, "Charmers," New Statesman \& Society, 29 May 1992.) 
shallow comments on the slightly less shallow story." ${ }^{\text {87 }}$ The marginalia consist of four different texts: slogans in rectangular squares, with a faded effect, as if stamped onto the page, reminiscent of the "Tales for an Accelerated Culture" on the cover; single panel cartoons; simple line drawings; and neologisms. The cartoons and drawings were done by Paul Rivoche, ${ }^{88}$ although to the specifications of Coupland who provided the text. ${ }^{89}$ The largest section of marginalia is the 95 neologisms - essentially, words made up by Coupland, along with their definitions. The most famous of these neologisms is perhaps the only one Coupland didn't invent ${ }^{90}$ — "McJob: A low-pay, lowprestige, low-dignity, low-benefit, no-future job in the service sector. Frequently considered a satisfying career choice by people who have never held one." ${ }^{\prime \prime}$

So, while Abbate is credited with designing the novel, others clearly had a strong hand in its design, including Coupland himself. As Abbate notes, "There are some books whose designs have to be coaxed laboriously into shape, and others that practically arrive on your desk fully realized due to the sheer personality of both the author and the manuscript. Douglas Coupland's Generation X: Tales for an Accelerated Culture was definitely the latter. My design goal was essentially to stay out of the way graphically and just allow Doug's characters and vision to shine." 92 Although Coupland has never openly taken credit for part of the novel's design, and has in fact denied it in interviews, saying that "writers have no power here," 93 it appears Abbate would disagree. In spite of his claims, it is important to note that Coupland is a visual artist as well as a novelist. Therefore, it is not hard to believe Abbate, especially after examining Coupland's book proposal for Generation X. In one version of the proposal, he describes the format of the novel: it will have "Io-I2 Line Drawings," "Iconographic doodles," "Side Bars," and a "Cool Design." Coupland felt that these design elements were essential since "the look and design is just as, if not more important

\footnotetext{
87 Boone, "First Novels," 5I.

88 Paul Rivoche also drew the cartoon strip "Generation X" in Vista magazine.

89 There are faxes from Paul Rivoche in the Coupland fonds in which Rivoche asks Coupland if the drawings are acceptable.

90 Although the Oxford English Dictionary credits the word's first usage to the Washington Post in 1986, it is evident that Coupland's novel popularized the word. In 2003, the word was added to the Merriam-Webster's Collegiate Dictionary, over protests from McDonald's.

9I Coupland, Generation X, 5 .

92 Abbate, "Following Douglas Coupland's Visual Cues."

93 Sturmanis, "That's How They All Became."
} 
than, the content. It is crucial, therefore, that this book achieve a marriage between the thoughts of a Generation and their look and their images." ${ }^{4}$ It appears that Coupland achieved his goal.

\section{"What's in a name?"}

Although most readers might assume that Coupland coined the term Generation X, the term had been in print for at least 40 years. ${ }^{95}$ But while Coupland did not coin it, his novel did popularize the use of the term to describe the generation born after the Baby Boom. Many critics have been quick to point out that Coupland borrowed the term for the title of his novel (which he does not deny), although no one is really clear which is the source text that inspired Coupland.

Generation $X$ was the title of a sociology book published in 1964 by Jane Deverson and Charles Hamblett ${ }^{96}$ which tried to explain the youth of the Sixties. Some critics, ${ }^{97}$ including Hamblett's son

94 Overview of Generation X, as book proposal, [c. 1987-I99I], Douglas Coupland Fonds, Box 009, File I4.

95 "In $1949, \ldots$ [Robert Capa] proposed an ambitious photo-essay project ... one that would focus on young people around the world ... As Capa explains, 'We named this unknown generation, The Generation X.' ... Originally slated to appear in $M c$ Call's, the project was withdrawn because of editorial differences. Versions of the piece eventually appeared in ... the January, February, and March 1953 issues of Holiday" (John M. Ulrich, "Generation X: A (Sub)Cultural Genealogy," in GenXegesis: Essays on "Alternative" Youth (Sub)Culture, ed. John M. Ulrich and Andrea L. Harris (Madison, WI: University of Wisconsin Press, 2003), 5). Interestingly enough, "the term 'Generation X' did not appear in the published photo-essays ... [however,] the term does make an appearance in the December 1952 issue of Holiday, as the heading for a brief column ... [This] marks the first time the term "Generation X" appears in print" (Ulrich, "Generation X," footnote 8).

96 Charles Hamblett and Jane Deverson, Generation X (London: Tandem Books, 1964).

97 "Here at last, so the hype has it, is the book that defines a twentysomething generation, Generation X: a term publishers seem inordinately pleased with, considering it has had a least two previous outings. First it was the title of an early I960s piece of youth-cult sociology"; "Peter York ... [cites] the fact that Generation X was actually the title of Jane Devison's ground-breaking study of delinquency in the early I960s"; "I have a crumbling paperback called Generation $X$ by Charles Hamblett and Jane Deverson, published in 1964, which ends with this ringing declaration: 'Every new Generation $X$ has the same problems and they can only be solved by growing up." (Williams, "Charmers"; 
Carey, ${ }^{98}$ feel that Derverson and Hamblett's work is the original source of Coupland's title. Coupland, however, has never identified this book as a possible inspiration for his title, and in a 1995 article in Details magazine, identified the "true" inspiration for his novel's title: "The book's title [Generation X] came not from Billy Idol's band, as many supposed, but from the final chapter of a funny sociological book on American class structure titled Class, by Paul Fussell. In his final chapter, Fussell named an "X" category of people who wanted to hop off the merry-go-round of status, money and social climbing that so often frames modern existence. The citizens of X had much in common with my own social disengaged characters; hence the title." 99 While this was not the first time Coupland had identified Fussell's book ${ }^{\mathrm{IOO}}$ as inspiration, it was the first time that he rejected the notion that his title came from Billy Idol's late-r97os punk band. Coupland has asserted that "many supposed" incorrectly that this is where the title came from, but, in fact, they had good reason to do so. In the original 1987 Vancouver magazine article that spawned the novel Generation X, Coupland states, "Generation X was the name of Billy Idol's band before he became just Billy Idol. Born in 1955, Billy is technically not an X himself, however he is a prime mover of the generation whose main claim to creative fame is the creation and abandonment of Punk style after members of the Baby Boom started ripping it off and using its motifs on menus and rayon jogging suits imported from Korea." This source is repeated in Vista magazine when Coupland started the "Generation X" comic strip, and in the many drafts of the book's proposal Coupland presented to his publishers. As Coupland writes in the overview of his novel Generation $X$ for prospective publishers, "Generation $X$ was a name coined in 1987 by Canadian writer Doug Coupland in a seminal article

Rebecca Pike, "So Little to Do and So Long to Do It," Sunday Times [London], April 26, 1992; Literary Review, "Generation X," August 1992.)

98 "It was not Douglas Coupland but my father, Charles Hamblett, and his cowriter, Jane Deverson, who first identified Generation X in 1964, in the book of the same name ... While Billy Idol attributed the name of his Seventies band to the book title, Douglas Coupland has not to my knowledge acknowledged it. As an original X-er, I would like to put the record straight" (Carey Hamblett, "Generation X; Letter," Times [London], January 17, 2004).

99 Douglas Coupland, "Generation X'd," Details, June 1995, http://Coupland. tripod.com/detailsı.html, (accessed I2 July 20I0).

Ioo Paul Fussell, Class: A Guide through the American Status System (New York: Summit Books, I983).

Ior Coupland, "Generation X," Vancouver Magazine, I69. 
that appeared that year in Vancouver magazine. It is taken from the name of Billy Idol's long-defunct punk band of the late r970s." It is unclear why Coupland wants Fussell's sociology book, rather than Billy Idol's punk band, to be credited as the inspiration for his novel's title. Whatever the reason for Coupland's decision to change his story of what inspired the title of his novel, it is interesting to note that it was not the novel's original title.

The draft book proposals for Generation X found in Coupland's archives show that when the book was being proposed as a piece of non-fiction it had different working sub-titles. These included both "An Introduction to that Strange Generation Born in the Sixties" and "The facts about that Strange Generation Born between 1957-1967."'03 These two subtitles focus on the original non-fiction nature of the book, but they also show that Coupland conceived of Generation X as the generation of citizens born between 1957 and 1967. As I discuss below, this definition is contentious. When Coupland submitted the manuscript to St. Martin's Press, the title and sub-title had been changed to It Can't Last: Tales from the X Generations. The revised sub-title of "tales" emphasizes the manuscript's shift from non-fiction to fiction and is clearly echoed in the novel's published sub-title, "Tales for an Accelerated Culture."

\section{Phenomenon of Generation X}

If Generation X was an ad agency wet-dream, if it froze a whole segment of youth culture in its headlights to be picked off by targetmarketers, is that really Douglas Coupland's fault? Can we blame him for infinitely annoying beer commercials and slacker sitcoms? All he did was get it right.

- Michael Brockington ${ }^{\text {I04 }}$

When Coupland proposed Generation $X$ to his publishers as a nonfiction guidebook about the generation following the baby boomers, he notes "it was ironic because there was no [such] generation at the

I02 Overview of Generation $X$ as book proposal, [c. 1987-1991], Douglas Coupland Fonds, Box 009, File I4.

I03 Draft of Generation X book proposal, [c. 1987-I99I], Douglas Coupland Fonds, Box 009, File II.

I04 Brockington, "Five Short Years." 
time." ${ }^{105}$ The story is told repeatedly by Coupland in interviews: "My publisher was horrified because there was no such thing as twentysomething back then. It was just 40 million people with this weird sort of amnesia thing"; "people in New York said I was just making up a fad"; "I was inventing something that didn't exist." In the late I980s when Coupland was writing articles for Vancouver and Vista magazine on the topic of Generation X, he was ahead of the rest of society. He was not necessarily trying to define a generation: "He says he's never really been able to answer why he began writing on the topic. He just always noticed that the unique world view he and his friends shared was never reflected in writing." ${ }^{\prime 107}$ Nevertheless, his novel Generation X has often been hailed as the novel that spurred the large cultural discussion that took place in the early I990s aiming to classify and understand this "new found" generation. Countless books were published on the topic_-ranging from sociological studies to business advice on how to successfully manage Generation Xers. ${ }^{\text {I08 }}$ While Coupland's novel surely played a large role in this social phenomenon, it was hardly the only text that played such a role. Coupland's text, however, was a major catalyst. The success of the novel put the concept of a new generation into the media's eye, and from there, other texts were quick to follow-and, more obviously, Coupland's novel offered a name for this new social phenomenon.

The inability to easily assign a single definition to the term Generation X, however, was part of the appeal and reason for the I990s media fascination with the label. Very few people agree on what (and to whom) the term actually refers. Sometimes, it is used to define a generation of people-i.e., all people born within a specific range of dates, normally the first generation after the Baby Boomers (or Yuppies, in Gen-X terminology). The Oxford English Dictionary defines Generation $\mathrm{X}$ as: "North Americans reaching adulthood in the I980s and 1990s."

ros Rebecca Howard, "X Marks Spot for Coupland's Ignored Generation," Daily News [Los Angeles], 26 August 1992.

106 Cotter, "His Generation"; McKinnon, "Generation X"; McQueen, "End to Identity Crisis."

107 Saenger, "The X-Man Writeth."

Io8 For a comprehensive list of the books that where spawned by the Generation $\mathrm{X}$ craze, see John M. Ulrich, "Introduction," Generation X: A Sub(Cultural) Genealogy (Madison, WI: University of Wisconsin Press, 2003).

109 Oxford English Dictionary, s.v. "Generation X," http://dictionary.oed.com/ (accessed i9 July 2010). 
non-fiction, he suggested that Generation X applied to those born between 1957 and 1967 . His, of course, is not the final word on the subject. As Carla Lucchetta observes, "Generation X was widely agreed upon as describing those born in the late 1950s and the 1960s, but an alternative usage has it applying to people born in the baby bust years between 1964 and the mid-I970s, and a third removes it from a specific birth era and grants it to anyone in their post-college 2os, the age of Coupland's characters in the book." "II As a term used to identify a specific generation based on birth year, it is most imprecise.

In practice, the term has also come to define a generation with a shared sensibility. Once Coupland decided that Generation $X$ would be fiction as opposed to non-fiction, he gravitated towards this definition. His article in Vancouver magazine describes a fictional character, Kevin, as "Generation X," which means, "He is overeducated, comes from the suburbs, wears nice clothes, has chronic employment difficulties, avoids politics, does not talk about religion, lives at home (but has had his own place a few times), and makes brilliant conversation." provides a similar definition for the term, although arguably more negative in tone: "[a] generation of young people ... perceived to be disaffected, directionless, or irresponsible, and reluctant to participate in society." "II2 These two definitions gesture toward the two opposing views of Generation X-namely, how they see themselves, and how others (i.e., the Baby Boomers) see them. The Gen Xers feel that they are living in a world in which the Baby Boomers have been granted everything, and have left nothing for their generation. The Baby Boomers, on the other hand, feel that the younger generation is simply unappreciative. These are vastly different views, and when we consider that Generation X includes over 40 million North Americans, it begins to explain the social drive to define and understand them.

In the late 1980s, the notion arose that the generation of North Americans who were in their twenties required a label. Brian Preston notes the use of the following terms, without a clear winner: "twentysomethings, the Boomlet, Slackers, the New Petulants and, more recently and definitively, Thirteeners ... [since they were the] thirteenth generation since American independence." ${ }^{\text {II3 }}$ It was around

\footnotetext{
io Lucchetta, "X Year after."

III Coupland, "Generation X," Vancouver Magazine, I65.

II2 Oxford English Dictionary, s.v. "Generation X," http://dictionary.oed.com/ (accessed in July 2010).

II3 Brian Preston, "Generation Next," Western Living, May I993, 32.
} 
this time that Coupland wrote his first article on Generation X and began circulating his book proposal among publishers. In retrospect, however, most critics agree that the conversation around the new generation in North America had already begun.

Coupland has always refused to take responsibility for the sudden social interest in Generation X, noting that he was simply writing about how he and his friends saw the world. As Coupland explains, "When the book was being sold in 1989, everyone said this guy is full of crap-there is no such generation. But then Time magazine did a cover story ${ }^{\mathrm{II}}$ and grudgingly, people seemed to acknowledge that we exist. I think you'll see that as people start to talk about it, my voice will be part of a chorus." "Is In "Generation X'd" which appeared in Details in 1995, Coupland further defined "this chorus," which included himself and his novel. "[In the summer of I99I,] a Texan my age named Richard Linklater released the movie 'Slacker,' which was filled with overeducated and underoccupied oddballs who loosely paralleled the characters in my book. And in Seattle, a new form of music was exploding. Its attitude had everything to do with withdrawal, contemplation, and seeking the margins - albeit with the volume knob cranked to eleven. As the media goes, two's nothing, but three's a trend. Thus were born the most abused buzzwords of the early 90s: 'generation X', 'slacker', and 'grunge."'I6 Coupland, and other Xers who were describing their generation, were able to understand the gestation and meaning of the term Generation X. The problem, according to Coupland and other Xers, was that the BabyBoomer-controlled media did not really care what the Xers thought of themselves. All the media wanted was a way to market products to this newly labeled generation.

In the early I990s, the desire to capture the Generation X market resulted in hundreds of articles, television programs, and books written on the topic. It was partly because of this concerted attempt to market the concept of Generation X with Coupland as spokesperson that the author sought to distance himself from the discourse. This culminated in a 1995 Details magazine article, in which Coupland wrote his famous eulogy for Generation X:

\footnotetext{
II4 Coupland is referring to the article by David M. Gross and Sophfronia Scott, "Proceeding with Caution: The Twentysomething Generation Is Balking at Work, Marriage and Baby-boomer Values. Why Are Today's Young Adults so Skeptical?," Time, I6 July I990, 56-62.

IIs Quoted in Dafoe, "Carving a Profile."

I16 Coupland, "Generation X'd."
} 
This demographic pornography was probably what young people resented most about the whole $\mathrm{X}$ explosion. I mean, sure, other fringe movements of the past - the 2os expats in Paris, the 50 B Beats, 6os Hippies, 7os Punks - all got marketed in the end, but X got hypermarketed right from the start, which was harsh.

In late I99I, after both political parties had called to purchase advice on X, I basically withdrew from the whole tinny discourse. And now I'm here to say that $\mathrm{X}$ is over. I'd like to declare a moratorium on all the noise, because the notion that there now exists a different generation - X, Y, K, whatever - is no longer debatable. Kurt Cobain's in heaven, Slacker is at Blockbuster, and the media refers to anyone aged thirteen to thirty-nine as Xers. Which is only further proof that marketers and journalists never understood that $\mathrm{X}$ is a term that defines not a chronological age but a way of looking at the world. ${ }^{\text {II }}$

This "eulogy" presents an interesting paradox. Coupland, who consistently refused to be labeled as spokesperson for his generation and agreed that he was not solely responsible for the social craze around Generation X, nonetheless felt that he had the authority and power to declare the term "Generation X" dead.

\section{Coupland as Spokesperson: The writer doth protest too much?}

From the beginning, Coupland was wary of being labeled the "voice of a generation." In the first published review of Generation X, which appeared in Rolling Stone in February I99I, a month before the book was released, Coupland said he did not want to speak for others. He explained, "I just got sent this article by Bret Easton Ellis and he's like 'We think...' and 'Our generation...' I thought 'Fuck off.' I can only speak for myself. I don't want to be typecast as the $X$ guy."II8 This comment demonstrates that not only did Coupland not want to be seen as speaking for others, but he also did not want others speaking on his behalf. This early rejection of being typecast as the "X guy," however, proved futile. For "even if he never accepted the mantle, there is little question Coupland became, almost instantly,

II7 Coupland, "Generation X'd."

II8 Quoted in Jenny Jedeikin and Robert Love, "Fiction for the Post-boom," Rolling Stone, 7 February 199I, I3. 
the voice of his generation." "I9 Soon, Coupland was being referred to as a guru, "a prophet," the "patron saint of the under-3o crowd," even the "pop philosopher prince." 220

Despite his media-appointed title, in interviews Coupland continued to reject labels. ${ }^{121} \mathrm{He}$ stressed that he was not "a guy who lives 'in some sort of bat cave with some sort of marketing computer,' that lets him do demographic treatises. What he writes is fiction." "122 Not all media critics, however, praised Coupland. In fact, some felt that he was simply selling out. As Richard Rayner writes, "Coupland ... finds himself transformed into a spokesman - an unwilling, though not that unwilling, voice of a generation. A New York Times piece on MTV jargon? Call Coupland. A letter on Kurt Cobain's suicide or analysis of the term 'Brazilification' (the widening of the gap between rich and poor)? Doug's your man. No one seems quite sure whether he's a poser or a prophet." ${ }^{23}$ It did not help that there was media hype surrounding the fact that even the White House had called Coupland for advice on Generation X. Some critics were able to see through the media hype, however, and tried to insert reason into the discussion of Coupland and Generation X. Lesley Jane Seymour notes, "It wasn't Coupland but the media that crowned him spokesperson for the twentysome-thing generation after the release of his surprise bestseller, Generation X. Unlike Bret Easton Ellis or Jay McInerney, Coupland didn't set out to make big bucks off the malaise of his generation." 24

II Lucchetta, "X Year after."

I20 Richard Rayner, "Garageland Guru," British Vogue, August 1995, I02; Mallon, "Generation X Man"; Ward, "Separated at Birth."

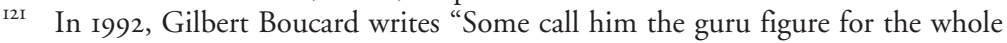
of Generation X. Coupland rejects the idea: 'I never use the pronoun "we" and don't see myself as a spokesperson. That is pretty rude, arrogant. I don't want people to speak for me and people can speak for themselves"'; Rebecca Howard points out the paradox: "Although he denies being a voice for a generation, he admits that his book may have brought attention to a group previously ignored"; and Damian Inwood observers, "Vancouver author Douglas Coupland shrugs off any suggestion that his Generation X fuelled success has made him a cult celeb. 'It's like being employee of the month at McDonald's,' he says, with a droll smile. 'You get your picture on the little plaque above the french fry computer." (Bouchard, "Coupland No Spokesperson"; Howard, "X Marks the Spot”; Damian Inwood, "After Generation X, ... Global Teens," Province [Vancouver], September 3, I992.)

${ }_{122}$ Lesley Jane Seymour, “A Generation X-plained," Mademoiselle, December I992, 56.

I23 Rayner, "Garageland Guru," IO2.

124 Seymour, "A Generation X-plained," 56. 
The media frenzy, and especially the calls he received about marketing Generation $X$, forced Coupland to stop granting interviews about Generation $X$ within a year of the novel's release. Coupland explains, "Around this time [199I] my phone started ringing with corporations offering from \$IO,000 and up to talk on the subject of How to Sell to Generation X. I said no. (The Gap asked me to do an ad. It was tempting, but I politely refused.)" 25 A decade after Generation $X$ was written, Coupland was asked in an interview if it was "a burden still being most well known as the Gen $X$ guy?" He replied: "Burden? No. I'd be ungrateful if I said otherwise. My dad knows there's some guy out there who painted soup cans, but he doesn't know the name Andy Warhol. Same difference. I should be so lucky." ${ }^{226}$ In the early I990s after the novel's release, Coupland was walking a fine line. On the one hand, he wanted to be regarded as an author of serious fiction, and sought to distance himself from the hype surrounding Generation X; he wanted to avoid being pigeonholed. On the other hand, he could not change the fact that his novel had played a role (some would argue a large role) in helping to define a generation.

\section{Conclusion}

Although Generation $X$ was so quickly dismissed by the panelists on CBC's Canada Reads, it should not be so easily dismissed by literary critics. G.P. Lainsbury argues that Generation $X$ "is a novel worth looking at seriously, if only for the influence it has had on contemporary culture." 27 I would argue that it is also worth looking at seriously for what its history can tell us about how an author can control the influence of his book by attempting to control aspects of its creation and reception. Throughout his career Coupland has had a strong hand not only in crafting his novels and their physical presentation, but also in crafting his image as author, and it began with Generation $X$. Whether it is his changing story about the inspiration for the novel's title, his various accounts of his publisher's expectations of his novel, or his refusing to take up the mantle of spokesperson for his generation, until it suited him to declare Generation X "dead,"

I25 Coupland, "Generation X'd."

${ }_{126}$ Ekow Eshun, "Generation Games," The Observer Magazine, 27 February 2000, 33.

I27 G.P. Lainsbury, "Generation $X$ and the End of History," I84. 
Coupland has carefully told and re-told the history of his novel over the last twenty years, without readers or critics recognizing what he has done or how he has done it. An examination of the rich and complex sociology of this "weird little book" helps us to understand how Coupland achieved what most authors dream of: having an impact on his readers, and changing society.

\section{SOMMAIRE}

Cet article propose une approche sociologique du roman de Douglas Coupland intitulé Generation X: Tales for an Accelerated Culture tout en retraçant les étapes de la création de l'œuvre depuis sa conception en tant qu'écrit documentaire paru dans un magazine en 1987 jusqu'à devenir en I99I un livre de fiction rédigé de la main même de Coupland.

Un consensus semble se dégager parmi les critiques littéraires sur ce que représente vraiment l'œuvre de Coupland - le roman qui a dépeint une génération - et ce, vingt ans après qu'elle a été publiée. L'opinion qui veut que ce roman exprime l'esprit d'une époque étiquetant du même coup son auteur de porte-parole de la génération $\mathrm{X}$ ne prend aucunement en compte le désaveu de cette perception par Coupland et l'attitude qu'a adoptée celui-ci lors de la réception de l'ouvrage. Cette étude ne prétend pas aborder la vraie histoire de Generation $X$ mais vise plutôt à relater les nombreuses anecdotes recueillies à propos de ce roman et auxquelles Coupland lui-même n'était pas étranger telles que ses hésitations dans le choix du titre de l'œuvre, ses multiples interventions en vue de combler les attentes de son éditeur et son refus de prendre le bâton du pèlerin à titre de porte-parole de sa génération au point de déclarer que la génération $\mathrm{X}$ était bel et bien «morte». S'il faut comprendre ce roman, son auteur ainsi que le phénomène social sans précédent qu'ils ont engendré, il est primordial de bien comprendre le contexte sociologique du texte. 